\title{
IMPACTS OF LEACHATE PERCOLATION ON GROUND WATER QUALITY: A CASE STUDY OF DHANBAD CITY
}

\author{
PANDE G. ${ }^{1}$ \\ SINHA A. ${ }^{2, *}$ \\ AGRAWAL ${ }^{3}{ }^{3}$
}

\author{
Gujarat Mineral Development Corporation, Bhavnagar, Gujarat, India \\ Department of Environmental Science and Engineering, Indian School of Mines \\ Dhanbad, Jharkhand, India
}

$B$ Tech Student, Department of Environmental Science and Engineering

Indian School of Mines, Dhanbad, Jharkhand, India

Received: 22/02/2014

Accepted: 20/01/2015

*to whom all correspondence should be addressed:

Available online: $18 / 02 / 2015$ e-mail: aloksinha11@yahoo.com

\begin{abstract}
This paper presents an assessment of the impact of uncontrolled and unscientific disposal of MSW on ground water in Dhanbad city, India. In this study, ground water quality around municipal solid waste disposal sites was investigated. Ground water quality analysis was carried out on samples collected at various distances from two disposal sites. The study has revealed that the ground water quality near dumping sites does not conform to the drinking water quality standards as per IS:10500. The impacts of indiscriminate dumping activity on ground water appeared most clearly as high concentrations of total dissolved solids, electrical conductivity, chlorides, chemical oxygen demand, and sulphates. High amount of metals like $\mathrm{Na}, \mathrm{K}, \mathrm{Ca}, \mathrm{Mg}, \mathrm{Cd}, \mathrm{Cu}, \mathrm{Ni}, \mathrm{Fe}, \mathrm{Zn}$ and $\mathrm{Mn}$ has also been detected in the groundwater samples near dumping area. Leachate characterization study also reveals high potential for groundwater contamination. Presence of feacal coliform contamination in groundwater samples indicates potential health risk for individuals exposed to this water.
\end{abstract}

Keywords: Municipal Solid Waste (MSW), Leachate, Ground water, Heavy Metals

\section{Introduction}

In developing countries like India per capita waste generation rates range from 0.2 to $0.6 \mathrm{~kg} / \mathrm{capita} / \mathrm{day}$ which is much lower compared to developed countries. Dhanbad, coal capital of India, had population of $2,684,487$ out of which 1,560,394 constitutes urban population. (Census, 2011). As there is no quantification of waste generated in the Municipal Corporation of Dhanbad, the estimates indicate that around 440 tons of waste is generated every day in the Municipal Corporation jurisdiction and the collection is about 165 tons (about 37 percent of the total waste generated). The waste produced comprises of $286 \mathrm{MT} \mathrm{d}^{-1}$ of domestic waste, $110 \mathrm{MT} \mathrm{d}^{-1}$ of commercial and hotel waste, and $44 \mathrm{MT} \mathrm{d}^{-1}$ of market waste. The per capita waste generation from the DMC is assumed as $300 \mathrm{gm}$ per capita per day as per CPHEEO norms. Accordingly, solid waste generation for 2026 is estimated at 776 MT (JNNURM, 2007). Currently, Dhanbad does not practice any scientific method of solid waste disposal. The waste collected from various localities in the Municipal Corporation is directly disposed off by open dumping on the lowlying area in the city. Solid wastes generated from all sanitary circles are disposed off at different localities.

Pande G., Sinha A. and Agrawal S. (2015), Impacts of Leachate Percolation on Ground Water Quality: A Case Study of Dhanbad City, Global NEST Journal, 17(1), 162-174. 
The current practices of the uncontrolled dumping of waste on the outskirts and inside Dhanbad have created a serious environmental and public health problem. Improper solid waste management leads to substantial negative environmental impacts (for example, pollution of air, soil and water, and generation of greenhouse gases from landfills), and health and safety diseases associated with different forms of pollution at local and global levels.

A number of incidences have been reported in the past, where leachate had contaminated the surrounding soil and polluted the underlying ground water aquifer or nearby surface water (Chain and DeWalle, 1976; Kelley, 1976; Lo, 1996; Mor et al., 2006). Even if there are no hazardous wastes placed in municipal landfills, the leachate is still reported as a significant threat to the groundwater (Lee, 2002). Contamination of groundwater resources due to improper solid waste disposal have been reported in many cities in India like Kanpur, Delhi and Chennai (Gopal et al., 1991; Olaniya et al., 1998; Kumaraswamy et al., 2000; Mor et al., 2006; Vasanthi et al., 2008). Since leachates are one of the major potential sources of ground water pollution when there is uncontrolled and unscientific disposal of MSW, the aim of the present study was to evaluate the impacts of leachate percolation on ground water quality in Dhanbad city.

\section{Objectives}

The primary goal of the study is to assess the impacts of careless dumping of MSW on ground water quality in Dhanbad city and to propose few remedial measures by suggesting proper MSW management techniques for Dhanbad city.

\section{Material and Methods}

\subsection{Study Area}

Dhanbad district of Jharkhand, also known as the "Coal Capital of India", lies between latitudes $23^{\circ} 39^{\prime} \mathrm{N}$ and $23^{\circ} 48^{\prime} \mathrm{N}$ and longitudes $86^{\circ} 11^{\prime} \mathrm{E}$ and $86^{\circ} 27^{\prime} \mathrm{E}$, covering an area of $450 \mathrm{~km}^{2}$. Giridih bound it in the north, Bokaro in the west, Purulia district in the south and Jamtara district in the east. It is connected through $\mathrm{NH}-2$ and $\mathrm{NH}-32$ from state capital and different district headquarters of the state. Dhanbad has an average elevation of $227 \mathrm{~m}$ (745 ft). Its geographical length (extending from North to South) is 43 miles and the breadth (stretching across East to West) is 47 miles. It shares its boundaries with West Bengal in the Eastern and southern part, Dumka \& Giridih in the North and Bokaro in the west. Dhanbad comes under the Chota Nagpur Plateau. Dhanbad features climate that is transitional between a humid subtropical climate and a tropical wet and dry climate. The average summer temperature is $44.5^{\circ} \mathrm{C}$ and winter average is $20^{\circ} \mathrm{C}$. The relative humidity during monsoon i.e. July-September may be as high as $100 \%$, while in summer months i.e. April-June, it decreases to as low as $20 \%$. Dhanbad areas receive more rainfall due to coal dust, which attracts clouds and brings rainfall to the area. The annual average rainfall for the last 10 years is $1598 \mathrm{~mm}$ per year. Damodar River is the main river flowing through the District. Katri, Jamunia, Gobai, Khudia and Irji are the other rivers flowing through the district (Fig. 1).

\subsection{Sampling Locations}

In current study two dumping locations were identified inside city (a) near cremation ground in Hirapur area (b) dump near vegetable and meat market in Police Line. The dumping sites recognized were residential as well a commercial area. The dumping sites are shown in figure 2 as landfill Site- 1 and Landfill Site-2 (marked in red circles). Groundwater samples were collected from nearby hand pumps such that they lie at a lower elevation from dumping points assuming that they lie down stream of dumping points. Two groundwater samples (S1 \& S2) were collected near dumping site-1 while one groundwater sample (S3) was collected near dumping site-2. Groundwater sample collected from Indian School of Mines (S4) 
served as a control sample as it lies in upstream of the landfill site/dumping site under consideration and may not be impacted by leachate percolation from landfill sites. The location of sampling points is depicted in Figure 2.

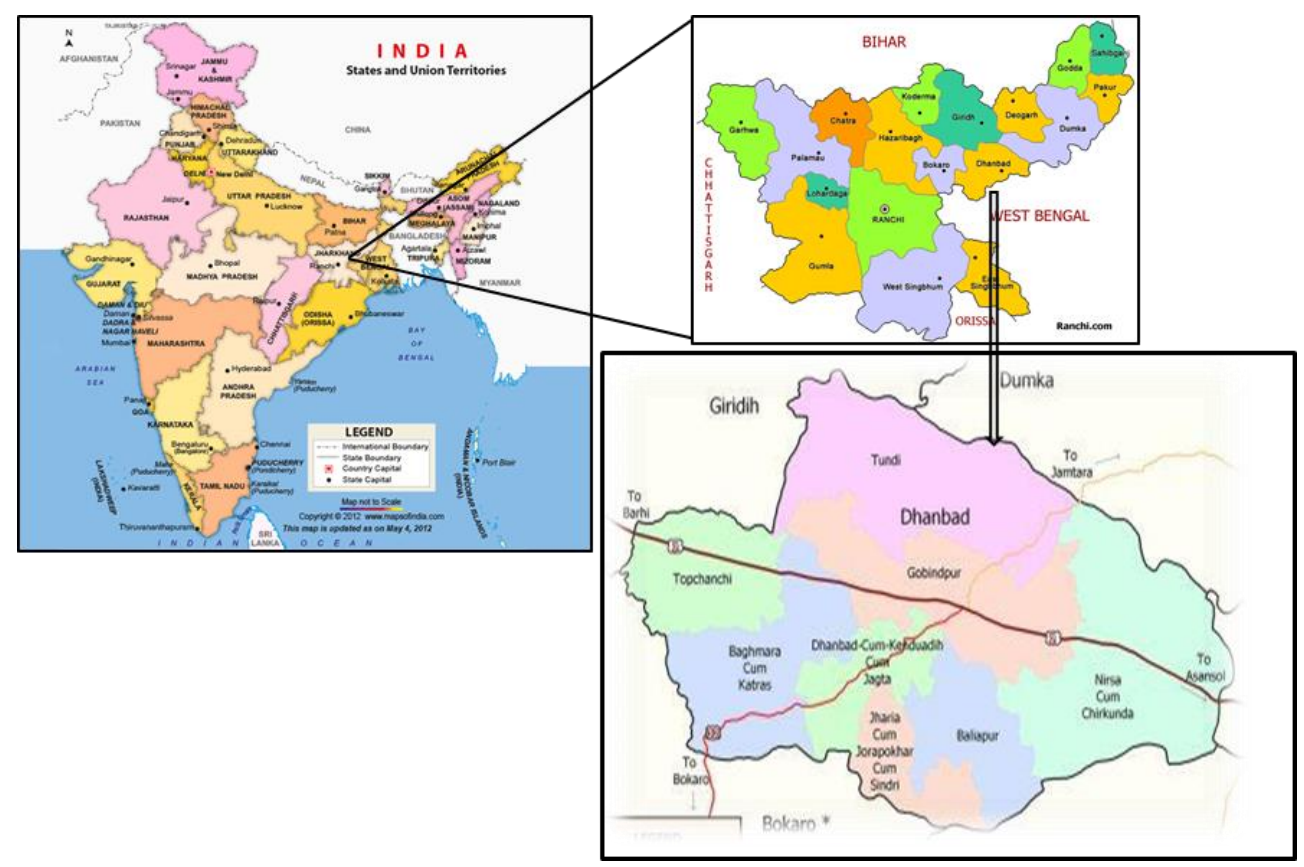

Figure 1. Map showing location of Dhanbad

\subsection{Collection Procedure}

For characterization of municipal solid waste grab samples were collected from the two dumping locations. 1-2 kg of sample (approx.) was collected and sealed in plastic bags. A total of ten representative solid waste samples, from each dump, were collected for characterization. The samples were brought at laboratory, and mixed. A representative amount of sample was taken from the mixed solid waste and sorted for characterization. The weight fraction of each component in the sorted sample was calculated. The mean waste composition was calculated using the results of the composition of each of the sorted samples. After manual sorting the MSW was classified into the following categories:

a) Organics: Paper (all kinds, magazines, newspapers, books, packaging materials and cardboard), Putrescibles (Food waste, yard waste, leaves), Plastics (PVC, PET, HDPE, LDPE, others), Wood, Textiles etc.

b) Inorganics: Glass (all kinds and colours), Metals (all kinds), Inert materials (stones, ground, construction and demolition wastes)

c) Miscellaneous: Nappies, sanitary napkins, thermocol etc. materials that do not fit in any of the above categories.

The total amount of collected Municipal solid waste sample from Police Line and dumping site in Hirapur was weighed in laboratory and it was found to be $34.8 \mathrm{~kg}$. During compositional study, the segregated sample was found to have different waste components like food, yard waste, plastic, paper, wood, textile, tin, dirt and miscellaneous wastes. Groundwater samples were collected in HDPE bottles (Tarsons, India) with 1 litre capacity for routine analysis. Samples were also collected in $250 \mathrm{ml}$ bottles and preserved with 
concentrated $\mathrm{HNO}_{3}$ to bring the $\mathrm{pH}$ below 2 for analysis of heavy metals in water samples. All samples were collected during winter season.

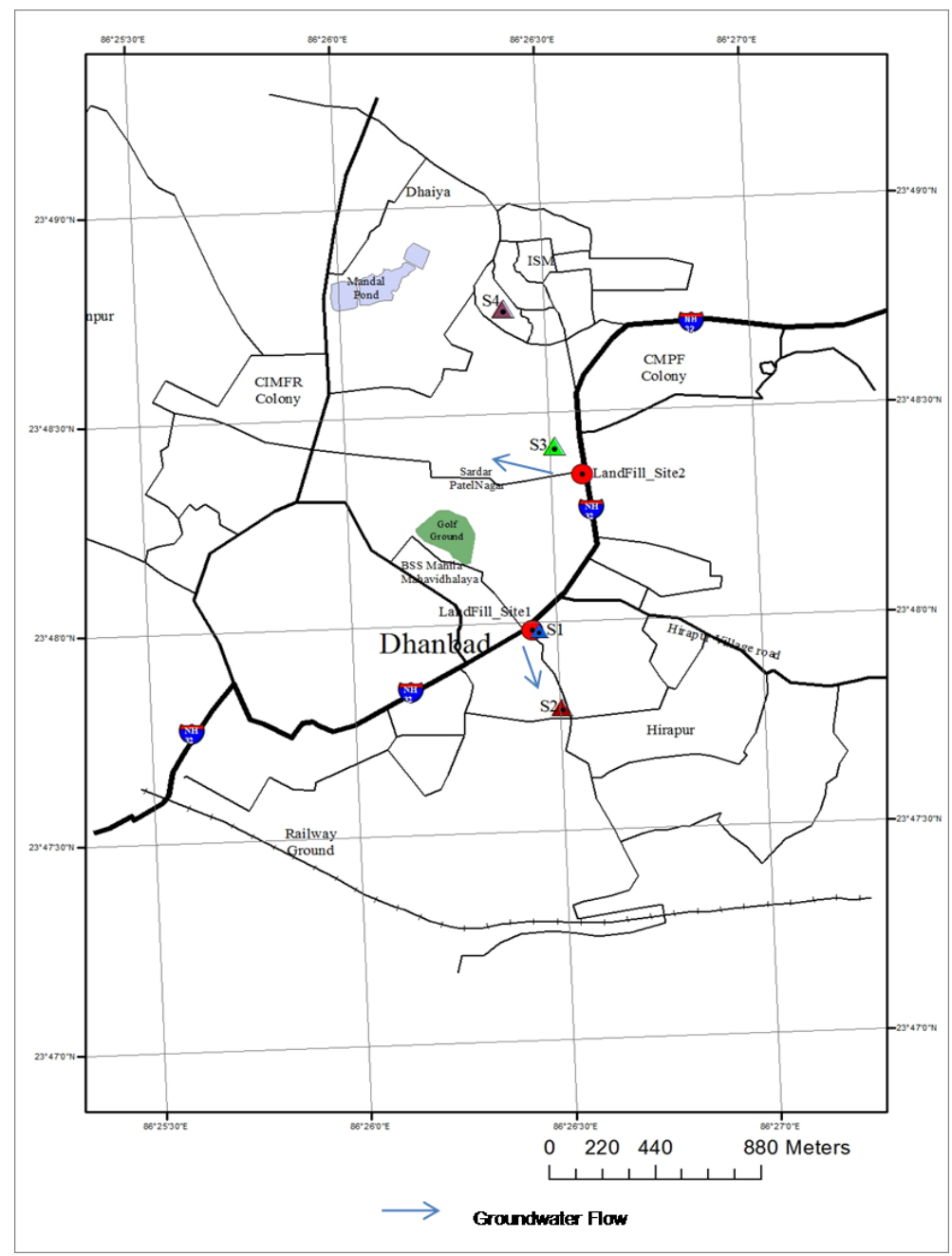

Figure 2. Map showing sampling locations and groundwater flow directions

\subsection{Leachate Extraction}

Near the dumping ground no leachate was found, hence, two leaching test protocols have been used to simulate the leaching processes of waste materials in landfill or other disposal scenarios to evaluate potential risks to human and/or groundwater. Toxicity Characteristic Leaching Procedure (TCLP; US EPA Method 1311, 2001) and open column percolation tests or lysimeter test (Karnchanawong and Yongpisalpop, 2009) have been used for simulation of leaching from municipal solid waste. The TCLP, or Toxicity Characteristic Leaching Procedure is designed to determine the mobility of both organic and inorganic analytes present in liquid, solid, and multiphasic wastes. This is usually used to determine if a waste may meet the definition of EP Toxicity, that is, carrying a hazardous waste code under RCRA (40 CFR Part 261) of D004 through D052. Millipore rotary agitator, 4, 2-liter bottle extractor (YT30ORAHW) was used for the extraction. The solid waste sample was milled/crushed/ grinded with the help of one roll crusher so as to pass through $9.5 \mathrm{~mm}$ (0.375 inch) standard sieve. TCLP extraction fluid was prepared by mixing $5.7 \mathrm{ml}$ acetic acid to $500 \mathrm{ml}$ of reagent water and adding $64.3 \mathrm{ml}$ of $1 \mathrm{~N} \mathrm{NaOH}$ solution and diluting the whole solution up to $1 \mathrm{I}$ and the $\mathrm{pH}$ was adjusted to 4.99. $50 \mathrm{~g}$ of MSW fine fraction was added with 1 
I of extraction fluid in TCLP bottles and rotated at a speed of 30 RPM for $18 \mathrm{~h}$ in TCLP extractor. Filtered extracts were preserved for analyses. For soluble heavy metal analysis, these filtered leachates were preserved with a drop of conc. nitric acid.

A column or Lysimeter test has also been used for simulation of leaching from waste. This test is often called a dynamic test as the leaching solution is under continuous flux and may be more representative of field conditions. This test involves the placement of waste material in a column or Lysimeter in compacted manner and then the addition of leaching solution to the material to produce leachate. Leaching solution used here was distilled water. 60 days leachate was collected, filtered and was preserved with a drop of conc. nitric acid for analysis. However, controlling experimental conditions for this test is not easy. Some operational problems, such as channeling and clogging of the column, may result.

\subsection{Analysis of Quality of Ground water and Leachate}

Since the leachate is reported as a significant threat to the groundwater (Lee, 2002), therefore leachates along with the ground water samples were analyzed for various physico- chemical and biological parameters to assess the water quality and leachate characteristics. Standard procedures as mentioned in (APHA, 1998) were used to determine color, turbidity, $\mathrm{pH}$, electric conductivity, total dissolved solids, total suspended solids, total hardness, calcium hardness, magnesium hardness, total alkalinity, chlorides, fluorides, nitrates, sulphates, cyanide, phenol, soluble COD, sodium, potassium, calcium, magnesium, and heavy metals. Along with this, the samples were also analyzed for Microbial presence. MPN (Most Probable Number) test was done to detect the coliforms in the samples of water. MPN Test for Total Coliforms was done by following the procedure as mentioned in code 9221, B, (APHA, 1998). Heavy metals like cadmium, copper, lead, nickel, iron, zinc, manganese and cobalt concentration levels were determined using Atomic Absorption Spectrophotometer (AAS), GBC Avanta. AAS standards from Merck were used for the calibration and standardization.

\section{Results and Discussions}

\subsection{Waste Composition}

The results of the waste physical composition analysis for Dhanbad city are shown in Table 1.

Table 1. Physical Composition of MSW

\begin{tabular}{|c|c|c|c|}
\hline $\mathbf{S N}$ & Sample & \% by weight (observed) & \% By Weight (Reference) \\
\hline \multicolumn{4}{|c|}{ ORGANICS } \\
\hline 1 & Food & 11.72 & $6-18$ \\
\hline 2 & Yard waste & 8.82 & $5-20$ \\
\hline 3 & Plastic & 19.35 & $4-10$ \\
\hline 4 & Paper & 30.16 & $25-40$ \\
\hline 5 & Wood & 0.42 & $1-4$ \\
\hline 6 & Textile & 0.76 & $0-4$ \\
\hline 7 & Msc. (Thermocol) & 0.36 & - \\
\hline \multicolumn{4}{|c|}{ INORGANICS } \\
\hline 8 & Tin (Other metals) & 0.55 & $2-8(1-4)$ \\
\hline 9 & Dirt/ Ash & 27.79 & $0-6$ \\
\hline
\end{tabular}

Reference source: Tchobanoglous et al. (1993) 
The main categories of waste identified were papers and plastics which share about $50 \%$ of total MSW. Putrescibles represent $21 \%$, followed by textile, tin and wood with a share of $0.76 \%, 0.55 \%$ and $0.42 \%$ respectively. A large share $(28 \%)$ is contributed by dirt which is also a considerable fraction in MSW.

\subsection{Characteristics of TCLP \& Lysimeter extractions}

The characteristics of the leachate samples, as obtained from TCLP analysis and Lysimeter tests, have been presented in Table 2.

Table 2. Analysis of TCLP \& Lysimeter extracts for various parameters

\begin{tabular}{|c|c|c|c|c|}
\hline \multirow{2}{*}{$\begin{array}{l}\text { S. } \\
\text { No. }\end{array}$} & \multirow{2}{*}{ Parameter } & \multicolumn{2}{|c|}{ TCLP Extract } & \multirow{2}{*}{ Lysimeter Extract } \\
\hline & & TCLP 1 & TCLP 2 & \\
\hline 1 & $\mathrm{pH}$ & 6.07 & 5.84 & 8.42 \\
\hline 2 & Color & Light Brown & Light Brown & Pale Yellow \\
\hline 3 & Odor & Pungent Smell & Pungent Smell & Pungent Smell \\
\hline 4 & $\mathrm{EC}\left(\mathrm{mmho} \mathrm{cm}^{-1}\right)$ & 6.61 & 6.63 & 3.89 \\
\hline 5 & Turbidity (NTU) & 125.0 & 111.0 & 85.0 \\
\hline 6 & TDS $\left(\mathrm{mg} \mathrm{l}^{-1}\right)$ & 7896.0 & 8114.0 & 4674.0 \\
\hline 7 & Total Hardness ( $\mathrm{mg} \mathrm{l}^{-1}$ as $\mathrm{CaCO}_{3}$ ) & 5366.0 & 7533.0 & 4300.0 \\
\hline 8 & Alkalinity (mg l-1 as $\left.\mathrm{CaCO}_{3}\right)$ & - & - & 3400.0 \\
\hline 9 & Chloride $\left(\mathrm{mg} \mathrm{l}^{-1}\right)$ & 107.96 & 101.96 & 235.92 \\
\hline 10 & Sulfate $\left(\mathrm{mg} \mathrm{l}^{-1}\right)$ & 43.36 & 47.99 & 32.40 \\
\hline 11 & Nitrate $\left(\mathrm{mg} \mathrm{l}^{-1}\right)$ & 9.78 & 9.48 & 8.07 \\
\hline 12 & $\operatorname{COD}\left(\mathrm{mg} \mathrm{l}^{-1}\right)$ & - & - & 4480.0 \\
\hline 13 & Sodium $\left(\mathrm{mg} \mathrm{l}^{-1}\right)$ & 1274.5 & 1226.4 & 1806.0 \\
\hline 14 & Potassium ( $\left.\mathrm{mg} \mathrm{l}^{-1}\right)$ & 108.0 & 110.4 & 1870.0 \\
\hline 15 & Calcium (mg l-1) & 491.7 & 497.0 & 425.1 \\
\hline 16 & Magnesium (mg l-1) & 666.9 & 910.9 & - \\
\hline 17 & Cadmium (mg l$\left.{ }^{-1}\right)$ & 0.006 & 0.005 & 0.021 \\
\hline 18 & Copper $\left(\mathrm{mg} \mathrm{l}^{-1}\right)$ & 0.007 & 0.004 & 0.101 \\
\hline 19 & Lead $\left(\mathrm{mg} \mathrm{l}^{-1}\right)$ & 0.071 & 0.065 & 0.324 \\
\hline 20 & Nickel $\left(\mathrm{mg} \mathrm{l}^{-1}\right)$ & 0.067 & 0.050 & 0.165 \\
\hline 21 & $\operatorname{Iron}\left(\mathrm{mg} \mathrm{l}^{-1}\right)$ & 17.275 & 18.560 & 1.022 \\
\hline 22 & Zinc $\left(\mathrm{mg} \mathrm{l}^{-1}\right)$ & 0.509 & 0.405 & 0.136 \\
\hline 23 & Manganese $\left(\mathrm{mg} \mathrm{l}^{-1}\right)$ & 2.228 & 1.890 & 0.068 \\
\hline 24 & Cobalt $\left(\mathrm{mg} \mathrm{l}^{-1}\right)$ & 0.051 & 0.048 & 0.094 \\
\hline
\end{tabular}

The $\mathrm{pH}$ value of the samples was found to be in range from 5.84 to 6.07 for TCLP analysis and 8.42 for Lysimeter tests. The relatively high values of EC and TDS indicate the presence of inorganic material in the samples. COD in Lysimeter extracts was found very high $\left(4480 \mathrm{mg} \mathrm{l}^{-1}\right)$, indicates the high organic strength. The total alkalinity was reported to be $3400 \mathrm{mg} \mathrm{l}^{-1}$. Likewise Total hardness was found high with the value of $7533 \mathrm{mg} \mathrm{l}^{-1}$. Multivalent cations, particularly $\mathrm{Mg}^{2+}$ and $\mathrm{Ca}^{2+}$ were reported considerably high, $\left(910 \mathrm{mg} \mathrm{I}^{-}\right.$ ${ }^{1}$ and $497 \mathrm{mg} \mathrm{l}^{-1}$ ) respectively for TCLP extracts and $425.1 \mathrm{mg} \mathrm{l}^{-1}$ for Lysimeter extracts. Similarly $\mathrm{Na}^{+}$was found in range of $1226.4 \mathrm{mg} \mathrm{l}^{-1}$ to $1806 \mathrm{mg} \mathrm{l}^{-1}$ and for $\mathrm{K}^{+}$the range varied from $108 \mathrm{mg} \mathrm{l}^{-1}$ to $1870 \mathrm{mg} \mathrm{l}^{-1}$ for TCLP extracts and Lysimeter extracts. Thus high values of the above parameters reports for significant organic and inorganic toxicity in the leachate. The high level of Fe (17-18 $\left.\mathrm{mg} \mathrm{l}^{-1}\right)$ in the leachate sample indicates that $\mathrm{Fe}$ and steel scrap are also dumped in the site. The dark brown color of the leachate is mainly attributed to the oxidation of ferrous to ferric form and the formation of ferric hydroxide colloids and 
complexes with fulvic/ humic substance (Chu et al., 1994). The presence of $\mathrm{Zn}\left(0.136-0.509 \mathrm{mg}^{-1}\right)$ in the leachate shows that the landfill receives waste from batteries and fluorescent lamps (Mor et al., 2006). $\mathrm{Pb}$ was reported as $0.324 \mathrm{mg} \mathrm{l}^{-1}$, the presence of $\mathrm{Pb}$ in the leachate samples indicates the disposal of $\mathrm{Pb}$ batteries, chemicals for photograph processing, $\mathrm{Pb}$-based paints and pipes at the landfill site (Mor et al., 2006). $\mathrm{Cu}\left(0.10 \mathrm{mg} \mathrm{l}^{-1}\right)$ and $\mathrm{Ni}\left(0.16 \mathrm{mg} \mathrm{l}^{-1}\right)$ were also present in the leachate samples. Trace amounts of Co $\left(0.09 \mathrm{mg} \mathrm{l}^{-1}\right)$ and $\mathrm{Cd}\left(0.02 \mathrm{mg} \mathrm{l}^{-1}\right)$ were also reported. Mn was found with the concentration of $2.2 \mathrm{mg} \mathrm{l}^{-1}$. A variety of waste is dumped which likely indicate the origin of $\mathrm{Zn}, \mathrm{Pb}, \mathrm{Cr}$, $\mathrm{Cu}$ and $\mathrm{Ni}$ in leachate (Mor, et al., 2006). The high heavy metal concentrations in leachate indicate potential for groundwater contamination below the landfill site as the site studied was unlined and unprotected. To assess the impact of improper dumping on groundwater, the quality of groundwater was determined in further studies.

\subsection{Ground Water Quality}

To study the possible impacts of leachate percolation on groundwater quality, concentration of various physico-chemical parameters including heavy metal ( $\mathrm{Cd}, \mathrm{Co}, \mathrm{Cu}, \mathrm{Fe} \mathrm{Ni}, \mathrm{Pb}$ and $\mathrm{Zn}$ ) concentration and microbiological parameters (total coliforms) were determined in groundwater samples. In addition with assessment of ground water quality near dumping site, its comparison with the ground water quality of a far away area from dumping site, i.e. at Indian School of Mines, was done to validate the probable impacts. Results have been shown in Table 3. The underground water of the studied area is used for domestic and other purposes. The $\mathrm{pH}$ of all the groundwater samples was about neutral, the range being 6.63 to 7.81 . Turbidity of sample 1 was found as 7.50 NTU, it shows higher amount of suspended and colloidal solids. EC for samples S1, S2 \& S3 were found high. High values of EC can be correlated with high amounts of dissolved solids. TDS indicates the general nature of water quality or salinity. The TDS for samples S1 and S2 was observed quite high, $750 \mathrm{mg} \mathrm{l}^{-1}$ and $906 \mathrm{mg} \mathrm{l}^{-1}$ respectively. As per the classification of Rabinove et al., (1958) based on TDS, both the above samples were non-saline. This high value of TDS may be due to the leaching of various pollutants into the groundwater. Olaniya and Saxena, (1977) also reported the groundwater pollution from refuse in the vicinity of the dumping sites detectable through increased TDS concentration of water. The high concentrations of TDS decrease the palatability and may cause gastrointestinal irritation in human and may also have laxative effect particularly upon transits. The concentration of Total Alkalinity as $\mathrm{CaCO}_{3}$ in groundwater was reported as $320 \mathrm{mg} \mathrm{l}^{-1}$ and $326 \mathrm{mg} \mathrm{l}^{-1}$ for samples S1 and S2 respectively. Water within the approximate $\mathrm{pH}$ range of 4.3 to 8.3 contains bicarbonate alkalinity and weak acids such as carbonic acid (carbon dioxide in solution) can also exist. Natural processes such as the dissolution of carbonate minerals and dissolution of $\mathrm{CO}_{2}$ gas from the atmosphere and soils could be a mechanism, which supply $\mathrm{HCO}_{3}{ }^{-}$into the groundwater. In addition, anthropogenic $\mathrm{CO}_{2}$ gas can be considered as a potential source of bicarbonate in groundwater. Potential sources of $\mathrm{CO}_{2}$ gas are, $\mathrm{CO}_{2}$ gas originating from municipal wastes within unlined landfill sites, $\mathrm{CO}_{2}$ gas due to the oxidation of organic materials leaked from old latrines and sewage systems in the downtown area, and $\mathrm{HCO}_{3}{ }^{-}$from sulfate reduction of organic materials in the aquifer. The high alkalinity imparts water with unpleasant taste, and may be deleterious to human health with high $\mathrm{pH}$, TDS and TH. Hardness is classified in two ways: (1) with respect to metallic ion and (2) with respect to the anions associated with the metallic ions.

Multivalent cations, particularly $\mathrm{Mg}^{2+}$ and $\mathrm{Ca}^{2+}$ are often present at a significant concentration in natural waters. These ions are easily precipitated and in particular react with soap to make it difficult to remove scum. TH is normally expressed as the total concentration of $\mathrm{Ca}^{2+}$ and $\mathrm{Mg}^{2+}$ in $\mathrm{mg} \mathrm{l}^{-1}$, equivalent $\mathrm{CaCO}_{3}$. Samples were obtained with significantly high values of total hardness, $467 \mathrm{mg} \mathrm{l}^{-1}$ and $537 \mathrm{mg} \mathrm{l}^{-1}$, equivalent $\mathrm{CaCO}_{3}$. Permanent hardness was found in range from $145 \mathrm{mg} \mathrm{l}^{-1}$ to $210 \mathrm{mg} \mathrm{l}^{-1}$. According to the classification for $\mathrm{TH}$ a very hard groundwater was dominantly distributed in the studied area. $\mathrm{Ca}^{2+}$ and $\mathrm{Mg}{ }^{2+}$ are the important parameters for total hardness. $\mathrm{Ca}^{2+}$ concentration in groundwater sample $\mathrm{S} 1$ was observed as $132 \mathrm{mg} \mathrm{l}^{-1}, 90.6 \mathrm{mg} \mathrm{l}^{-1}$ in sample S2 and $108 \mathrm{mg} \mathrm{l}^{-1}$ in sample S3, whereas $\mathrm{Mg}^{2+}$ concentration was reported as significantly high in sample 2 as $148.80 \mathrm{mg} \mathrm{l}^{-1}$. Hence study showed that the major portion of hardness 
in sample 2 was contributed by $\mathrm{Mg}^{2+}$ as magnesium hardness $\left(310 \mathrm{mg} \mathrm{l}^{-1}\right) . \mathrm{Mg}^{2+}$ salts are cathartic and diuretic and high concentration may cause laxative effect. The concentration of $\mathrm{Na}^{+}$in water samples 1,2 and 3 were found $32 \mathrm{mg} \mathrm{l}^{-1}, 27 \mathrm{mg} \mathrm{l}^{-1}$ and $61.2 \mathrm{mg} \mathrm{l}^{-1}$, respectively.

Table 3. Ground Water Quality Assessment

\begin{tabular}{|c|c|c|c|c|c|c|}
\hline $\begin{array}{l}\text { S. } \\
\text { No. }\end{array}$ & Parameter & $\begin{array}{l}\text { Sample } 1 \\
\text { (S1) }\left(\mathrm{mg} \mathrm{l}^{-1}\right)\end{array}$ & $\begin{array}{l}\text { Sample } 2 \\
\text { (S2) }\left(\mathrm{mg} \mathrm{l}^{-1}\right)\end{array}$ & $\begin{array}{l}\text { Sample } 3 \\
\text { (S3) }\left(\mathrm{mg} \mathrm{l}^{-1}\right)\end{array}$ & $\begin{array}{l}\text { Sample } 4 \\
\text { (S4) }\left(\mathrm{mg} \mathrm{l}^{-1}\right)\end{array}$ & $\begin{array}{c}\text { IS:10500 } \\
(2012) \\
\left(\mathrm{mg} \mathrm{l}^{-1}\right)\end{array}$ \\
\hline 1 & $\mathrm{pH}$ & 7.59 & 7.81 & 6.63 & 6.73 & $6.5-8.5$ \\
\hline 2 & Color (Hazen) & Colorless & Colorless & Pale yellow & colorless & 5 \\
\hline 3 & Odor & $\begin{array}{c}\text { Unobjectionab } \\
\text { le }\end{array}$ & $\begin{array}{c}\text { Unobjectionab } \\
\text { le }\end{array}$ & $\begin{array}{c}\text { Unobjectionab } \\
\text { le }\end{array}$ & $\begin{array}{c}\text { Unobjectionab } \\
\text { le }\end{array}$ & - \\
\hline 4 & $\mathrm{EC}\left(\mathrm{m} \mathrm{mhos}_{\mathrm{cm}} \mathrm{cm}^{-1}\right)$ & 1.24 & 1.31 & 0.95 & 0.174 & - \\
\hline 5 & Turbidity (NTU) & 7.50 & 0.0 & 5.2 & 1.2 & 1 \\
\hline 6 & TSS & 18.0 & 22.0 & 46.0 & 2.0 & - \\
\hline 7 & TDS & 750.0 & 906.0 & 420.0 & 124 & 500 \\
\hline 8 & $\begin{array}{c}\text { Total hardness }\left(\mathrm{mg} \mathrm{l}^{-1}\right. \\
\left.\text { as } \mathrm{CaCO}_{3}\right)\end{array}$ & 466.66 & 536.66 & 301.66 & 296 & 200 \\
\hline 9 & $\begin{array}{l}\text { Calcium hardness } \\
\left(\mathrm{mg} \mathrm{l}^{-1} \text { as } \mathrm{CaCO}_{3}\right)\end{array}$ & 330.0 & 226.66 & 270.0 & 188 & - \\
\hline 10 & $\begin{array}{c}\text { Magnesium hardness } \\
\left(\mathrm{mg} \mathrm{l}^{-1} \text { as } \mathrm{CaCO}_{3}\right)\end{array}$ & 136.66 & 310.00 & 31.66 & 108 & - \\
\hline 11 & $\begin{array}{c}\text { Alkalinity } \\
\left.\text { (mg l-1 as } \mathrm{CaCO}_{3}\right)\end{array}$ & 320.0 & 326.66 & 156.60 & 84.3 & 200 \\
\hline 12 & Chloride & 111.96 & 113.96 & 111.96 & 48.5 & 250 \\
\hline 13 & Sulfate & 29.69 & 41.22 & 125.39 & 25.2 & 200 \\
\hline 14 & Nitrate & 14.60 & 14.57 & 5.34 & 3.70 & 45 \\
\hline 15 & MPN Index/100 ml & - & 900 & $>1600$ & $<1.2$ & NIL \\
\hline 16 & COD & 25 & 32 & 192 & 2.0 & - \\
\hline 17 & Fluoride & $<0.05$ & $<0.05$ & $<0.05$ & $<0.05$ & 1.00 \\
\hline 18 & Phenolic compounds & $<0.001$ & $<0.001$ & $<0.001$ & $<0.001$ & 0.001 \\
\hline 19 & Cyanide & $\mathrm{BDL}$ & BDL & $\mathrm{BDL}$ & $\mathrm{BDL}$ & 0.05 \\
\hline 20 & Sodium & 32.4 & 27.0 & 61.20 & 4.8 & - \\
\hline 21 & Potassium & 1.15 & 0.10 & 4.22 & 0.15 & - \\
\hline 22 & Calcium & 132.0 & 90.6 & 108.0 & 75.20 & 75 \\
\hline 23 & Magnesium & 65.60 & 148.80 & 15.20 & 51.84 & 30 \\
\hline 24 & Cadmium & 0.040 & $<0.0004$ & $<0.0004$ & $<0.0004$ & 0.003 \\
\hline 25 & Copper & 0.038 & $<0.001$ & $<0.001$ & $<0.001$ & 0.05 \\
\hline 26 & Lead & $<0.01$ & $<0.01$ & $<0.01$ & $<0.01$ & 0.01 \\
\hline 27 & Nickel & 0.011 & 0.009 & $<0.005$ & $<0.005$ & 0.02 \\
\hline 28 & Iron & 0.431 & 0.079 & 0.104 & 0.022 & 0.3 \\
\hline 29 & Zinc & 1.146 & 0.096 & 1.615 & $<0.0005$ & 5 \\
\hline 30 & Manganese & 0.041 & 0.004 & 0.795 & $<0.02$ & 0.1 \\
\hline 31 & Cobalt & $<0.05$ & $<0.05$ & $<0.05$ & $<0.05$ & - \\
\hline
\end{tabular}

According to USEPA the safe concentration of $\mathrm{Na}^{+}$was fixed as $20 \mathrm{mg} \mathrm{l}^{-1}$. The high concentration of $\mathrm{Na}^{+}$ may pose a risk to persons suffering from cardiac, renal and circulatory disease. $\mathrm{K}^{+}$has been reported to be an indication of the leachate effect (Ellis, 1980). The concentration of $\mathrm{K}^{+}$in the water samples were obtained quite low. The concentration of anions $\mathrm{Cl}^{-}, \mathrm{F}^{-}, \mathrm{NO}_{3}{ }^{-}, \mathrm{SO}_{4}{ }^{2-}$ in the groundwater samples were found within the prescribed limit. Phenol was also observed as below detection limits in water samples along with cyanides. COD is a measure of oxygen equivalent to the organic matter content of the water 
susceptible to oxidation by a strong chemical oxidant and thus is an index of organic pollution. The COD level in the groundwater samples varied from 25 to $32 \mathrm{mg} \mathrm{l}^{-1}$, indicating the presence of organic contaminants in the water and can be used as organic indicators to assess the groundwater pollution caused by dumping of MSW. The groundwater samples were analyzed for heavy metal such as $\mathrm{Cu}, \mathrm{Fe}, \mathrm{Zn}$, $\mathrm{Co}, \mathrm{Ni}, \mathrm{Pb}, \mathrm{Cd}, \mathrm{Mn}$. Sample 1 was found to have Iron as $0.431 \mathrm{mg} \mathrm{l}^{-1}$ which was beyond the permissible limit $\left(0.3 \mathrm{mg} \mathrm{l}^{-1}\right)$ prescribed by IS: 10500 . Presence of Fe in water can lead to change of color in groundwater. They can cause objectionable taste and appearance in water. Further $0.04 \mathrm{mg} \mathrm{l}^{-1}$ of $\mathrm{Cd}$ was found in the same sample of ground water which was also observed exceeding the prescribed limit of $0.003 \mathrm{mg} \mathrm{l}^{-1}$. Cd is highly toxic in nature. It may cause toxic effects in kidney. However other heavy metals were found in the prescribed limits. Presence of these heavy metals in ground water is showing the serious toxic risks of contamination due to percolation of leachate. The concept of coliforms as bacterial indicator of microbial water quality is based on the premise that coliforms are present in high numbers in the faeces of humans and other warm-blooded animals. If faecel pollution enters in groundwater, it is likely that these bacteria will be present, even after significant dilution. Results have shown the presence of TC in sample 2 and sample 3, indicating the contamination of groundwater possibly due to leachate percolation in groundwater. The coliforms bacteria can multiply where leachate enters an oxygenated system. Stuart and Klinck, (1999), found that when leachate was diluted with the bacteria-free groundwater there was an increase in the number of thermo tolerant coliforms and the bacteria were able to survive for up to two weeks under laboratory conditions. This shows a more critical problem. Thus the presence of faecal contamination is an indicator that a potential health risk exists for individual exposed to this water. The problem of high pathogenic contamination in groundwater may be attributed to the non availability of sewer lines in Dhanbad and due to percolation of sewage discharged by the residents in open areas. The sample S3 had a coloration of pale yellow which points towards the serious contamination of the groundwater. Since the location of S3 was down stream to the dump of vegetable and meat market the chances of organic and pathogenic contamination of groundwater was high. As predicted, a high amount of total coliforms (>1600) were observed in the sample. Similarly COD value of $192 \mathrm{mg} \mathrm{l}^{-1}$ showed some organic contamination in the water.

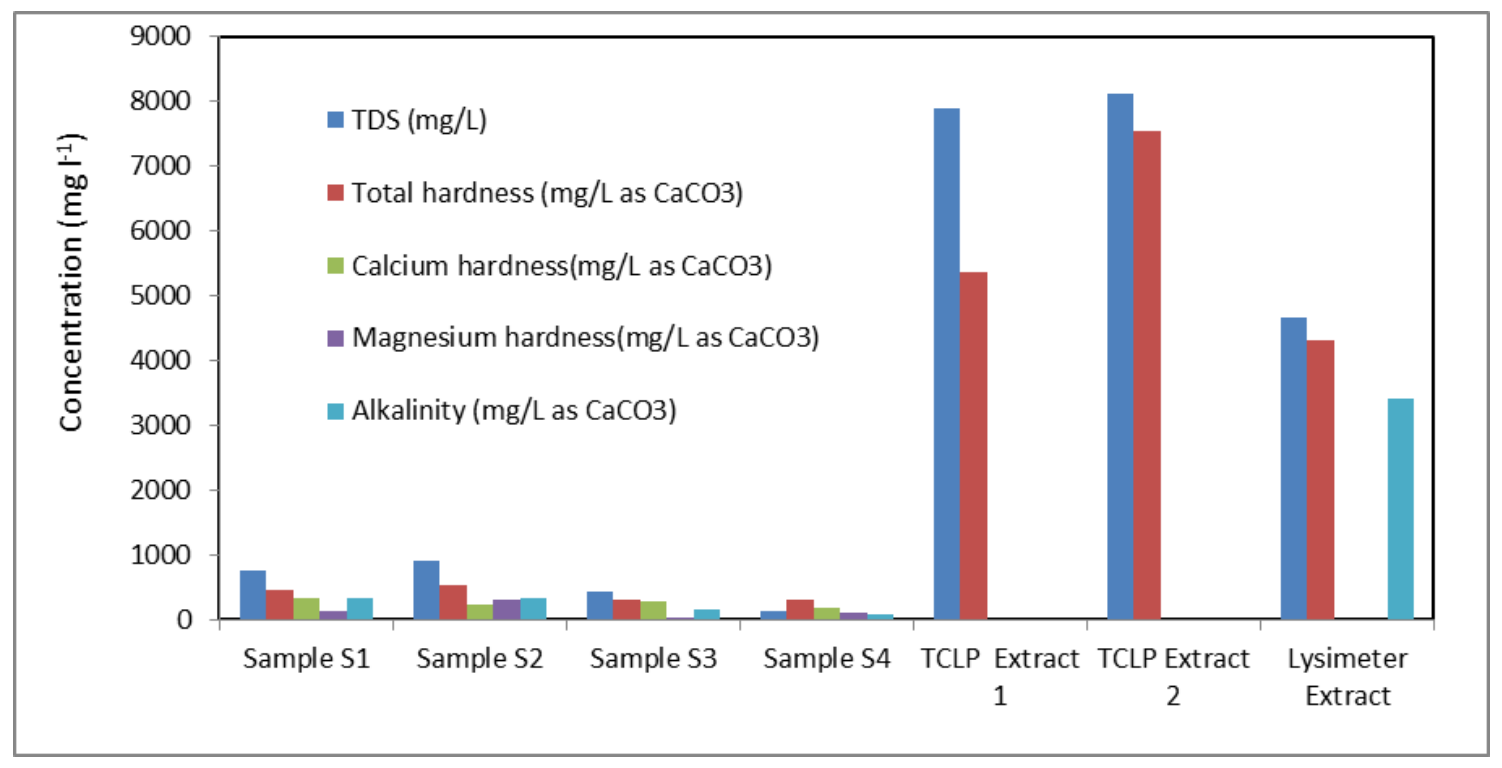

Figure 3. Bar diagram showing impact of leachate on TDS, Total hardness and alkalinity of groundwater 
On heavy metal analysis $\mathrm{Mn}$ was found around $0.79 \mathrm{mg} \mathrm{l}^{-1}$, which was significantly high. Fe was reported near $0.104 \mathrm{mg} \mathrm{l}^{-1}$. Though $\mathrm{Mn}$ does not show any toxic effect in ground water, but high values may impart taste and color.

The concentration of Fe also contributes in coloration. $\mathrm{Na}^{+}$and $\mathrm{K}^{+}$concentrations were reported as slightly high, $61.2 \mathrm{mg} \mathrm{l}^{-1}$ and $4.22 \mathrm{mg} \mathrm{l}^{-1}$ respectively. In comparative study of the groundwater quality near dumping sites to the groundwater at control site (S4) at Indian School of Mines, Dhanbad, most of the above parameters discussed were found within the prescribed limit of drinking water standards IS:10500 (2012). Hence, it is imperative that the groundwater quality in vicinity to dumping sites have deteriorated due to the percolation of leachate from dumping sites. Figure 3-7 shows the comparison of groundwater quality with the quality of leachate by bar chart diagrams. It may be inferred that TDS, hardness, chloride, sulfate, COD and metals like sodium, calcium, cadmium, copper, nickel, iron, zinc and manganese, in groundwater, have increased due to percolation of leachate from unlined dumping areas in the city of Dhanbad. Moreover, high MPN values in groundwater indicate leaching of toxic wastewater in subsurface.

Comparing the water quality parameters of Sample 1,2,3 with sample 4 reveals that high levels of TDS, conductivity, chlorides, sulfates, COD, sodium, cadmium, copper, nickel, iron and manganese has been due to the MSW dumping activities in the area. Groundwater in Dhanbad is generally hard and hence high values of total hardness, calcium and magnesium ions cannot be attributed to the contamination by leachate percolation (Chatterjee et al., 2010). However high values of MPN in groundwater samples pose a serious threat to the local population and may be due to percolation of toxic leachates from dumping sites.

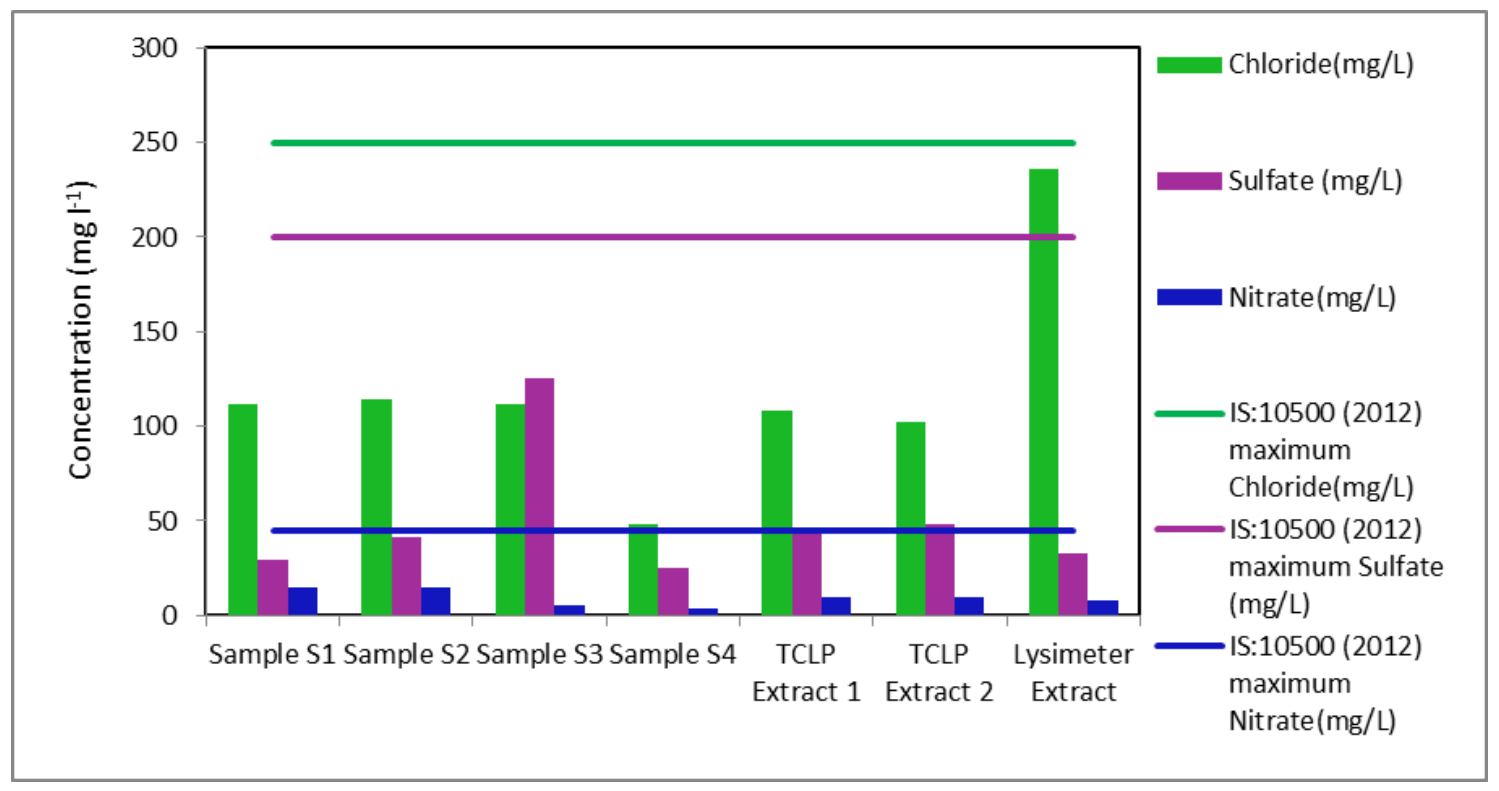

Figure 4. Bar diagram showing impact of leachate on anions of groundwater 


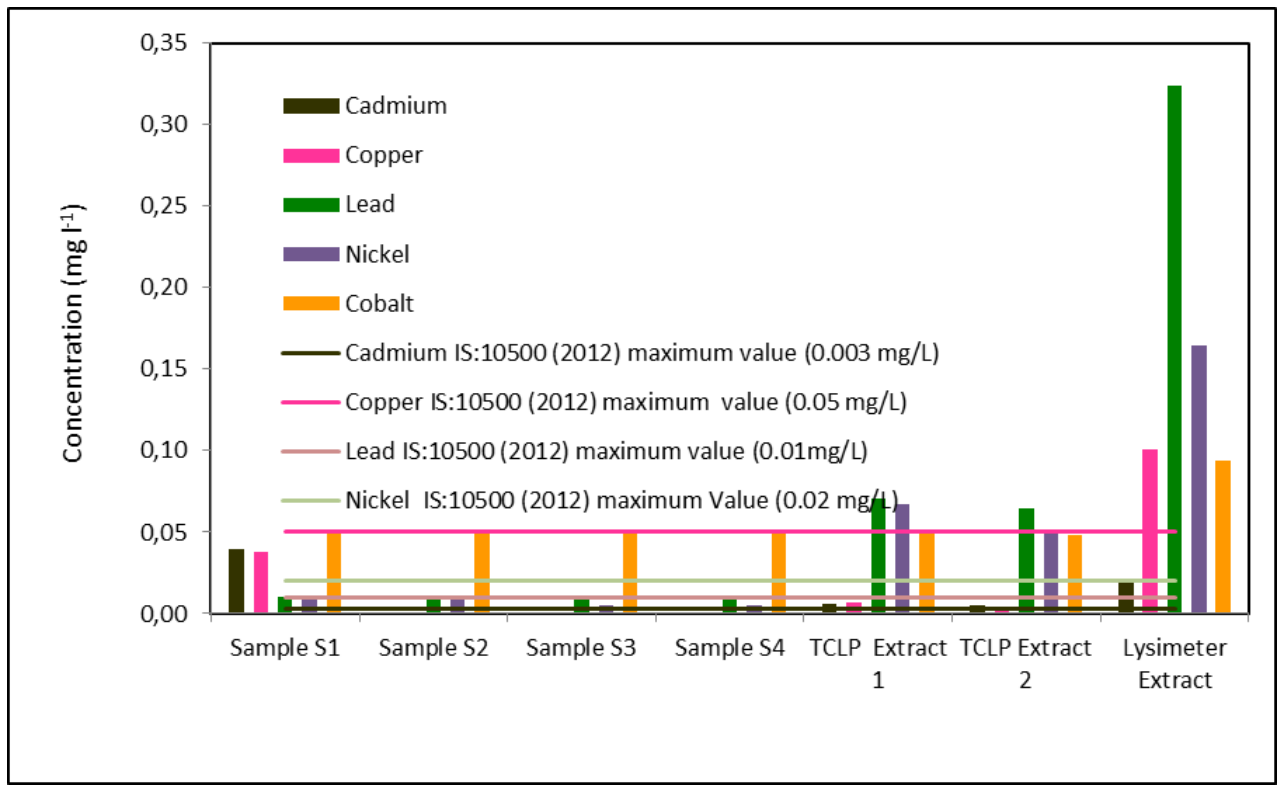

Figure 5. Bar diagram showing impact of leachate on metal concentration ( $\mathrm{Cd}, \mathrm{Cu}, \mathrm{Pb}, \mathrm{Ni} \& \mathrm{Co})$ of groundwater

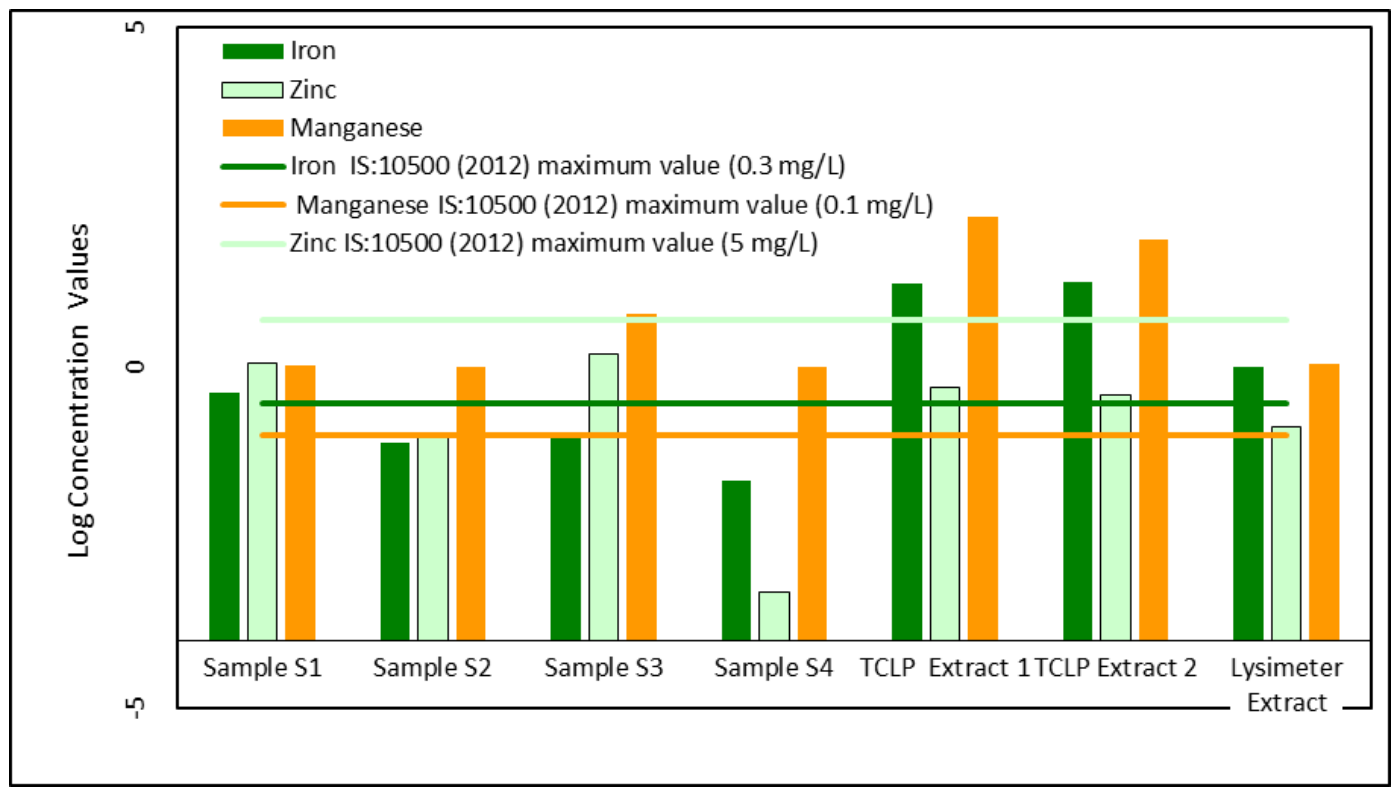

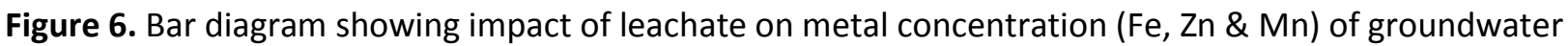

\section{Conclusions}

The study of ground water quality has revealed the toxic effects of leachate percolation in ground water and the ground water quality, near the dumping sites, does not conform to the drinking water quality standards as per IS:10500 (2012). However, groundwater quality in a control area, far away from dumping sites, shows no significant impact except hardness and alkalinity, which may be due to geological strata of the region. Therefore, scientific disposal of MSW is the need of the hour along with the proper facility for 
leachate treatment. It may be concluded that the ground water in and around the landfill sites shall not be used for drinking purposes unless it is properly treated and conforms the drinking water quality standards.

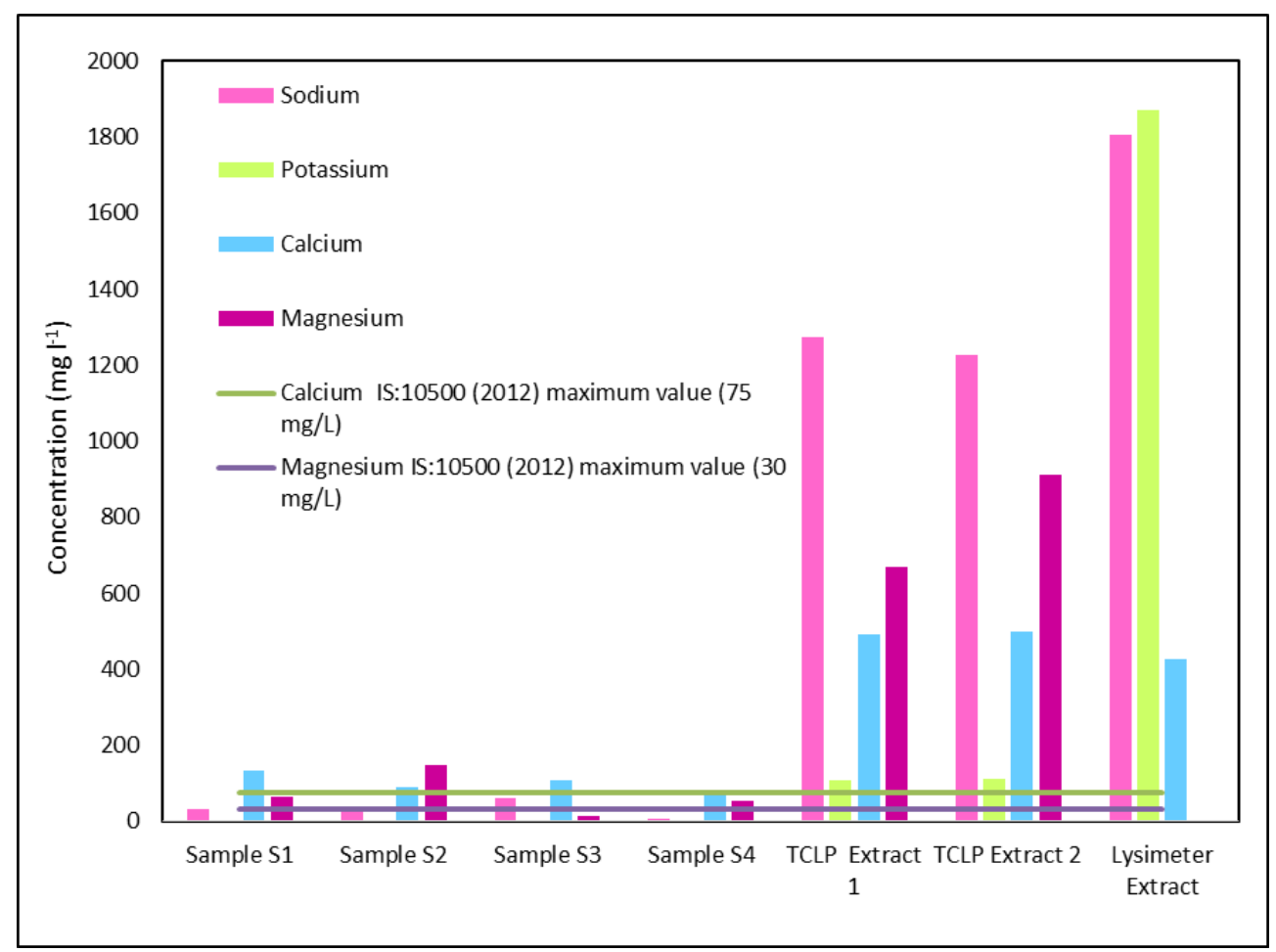

Figure 7. Bar diagram showing impact of leachate on metal concentration ( $\mathrm{Na}, \mathrm{K}, \mathrm{Ca} \& \mathrm{Mg}$ ) of groundwater

\section{References}

APHA-AWWA-WPCF, Standard Methods for the Examination of Water and Wastewater, 15th Eds American Public Health Association, Washington, DC, USA (1998).

Bureau of Indian Standards (BIS) (2012), Indian standard specification for drinking water, IS: 10500, pp. 2-4.

Census (2011) http://www.census2011.co.in/census/district/96-dhanbad.html (as cited on 20/12/2014)

Chain E.S.K. and DeWalle F.B. (1976), Sanitary Landfill Leachates and Their Treatment, ASCE, Journal of Environmental Engineering Division, 102, 8, 411-431.

Chatterjee R., Tarafder G. and Paul S. (2010), Groundwater quality assessment of Dhanbad district, Jharkhand, India, Bull Eng Geol Environ, 69, 137-141.

Chu L.M., Cheung K.C. and Wong M.H. (1994), Variations in the chemical properties of landfill leachate, Environmental Management, 18, 105-117.

Ellis J.A. (1980), Convenient parameter for tracing leachate from sanitary landfills, Water Research, 14, 1283-1287.

Gopal D., Singh R.P. and Kapoor R.C. (1991), Ground water pollution by solid wastes -A case study. Pollution Research, Enviro Media, 10, 111-116.

Jawahar Lal Nehru National Urban Renewal Mission (JNNURM) (2007), City Development Plan for Dhanbad, Dhanbad Municipal Corporation.

Karnchanawong S. and Yongpisalpop P. (2009) Leachate Generation from Landfill Lysimeter using Different Types of Soil Cover, World Academy of Science, Engineering and Technology, 3(3), 418-422. 
Kelley W.E. (1976), Ground-Water Pollution near a Landfill, ASCE, Journal of Environmental Engineering Division, 102, 1189-1199.

Kumaraswamy N., Subramanyan B. and Kotaiah B. (2000), Movement of groundwater pollution in and around a solid waste disposal site- a case study, Indian Journal of Environmental Protection, 20, 206-208.

Lee G.F. (2002), Solid Waste Management: USA Lined Landfill Reliability, Natural Resources Forum, A United Nations Journal, New York.

Lo I.M.C. (1996), Characteristics and Treatment of Leachates from Domestic Landfills, Environment International, 22(4), 433-442.

Mor S., Ravindra K., Dahiya R.P. and Chandra A. (2006), Leachate Characterization and Assessment of Groundwater Pollution Near Municipal Solid Waste Landfill Site, Environmental Monitoring and Assessment, 118(1-3), 435-456.

Olaniya M.S. and Saxena K.L. (1977), Ground water pollution by open refuse dumps at Jaipur, Indian Journal of Environmental Health, 19, 176-188.

Olaniya M.S., Khandekar P. and Bhide A.D. (1998), Ground Water Pollution due to Refuse leachate: A Lab Study, Indian Journal of Environmental Protection, 18(10), 748-751.

Rabinove C.J., Long Ford R.H. and BrookHart J.W. (1958), Saline water resource of North Dakota, U.S. Geol. Sur. Water Supply Paper, 1428, 72.

Stuart M.E. and Klinck B.A. (1999), Human risk in relation to landfill leachate quality, British Geological Survey Technical Report WC/99/17-45 pp, British Geological Survey Keyworth UK.

Tchobanoglous G., Theisen H. and Vigil, S. (1993), Integrated Solid Waste Management Engineering Principles and Management Issues, McGraw-Hill Higher Education, New York.

Vasanthi P., Kaliappan S. and Srinivasaraghavan R. (2008). Impact of poor solid waste management on ground water, Environmental monitoring and assessment, 143(1-3), 227-238. 